\title{
MARIOLOGICAL DIMENSION OF THE THEOLOGICAL AND PASTORAL CONCEPTS OF CARDINAL STEFAN WYSZYŃSKI, PRIMATE OF POLAND
}

\section{Introduction}

At the intersection of all the ways leading to salvation revealed in the Old and New Testament framework stands the Blessed Virgin Mary with her reference to the mystery of the Triune God. In the thought of Cardinal Wyszyński, however, this reference appears in the reflection of faith as a phenomenon that can never be fully explored and seems to be inexpressible. And yet, despite this, it continues to emerge as an essential truth in the life of faith and the consciousness of the Church. It is because the Blessed Virgin Mary was gifted with God's Motherhood and marked with a tangible experience of God's goodness in his Son Jesus Christ, of whom she is the Mother. However, the term "mother" must be given a supernatural meaning.

In this context, Cardinal Wyszyński's teaching attempts to answer the question: in what sense did Mary participate and continue to collaborate in granting the Church the grace of God and introducing the Church to mysterious participation in God's nature? As he emphasized, the Blessed Virgin Mary was able to experience both physically and personally, this Child who was her God as well as her Savior. This experience has positioned her functionality for the Church. Because the Blessed Virgin Mary experienced God like no one else, the Church had taken her to herself, to be truthfully directed to Jesus Christ as Lord and Savior. The Marian experience of God's motherhood, the practice of her faith, remains such a one-off experience and a unique mystery of faith. Nevertheless, this one-off is open to the Church and her reflection of faith.

In this sense, the Virgin Mary is the Mother of God-Man, Jesus Christ, who is also the Head of the Mystical Body - the Church. Members of the Church understood as Mystical Body of Christ are all people who belong to Him in many different ways. As Cardinal Wyszyński put it, Mary's motherhood, initiated in the Mystery of the Incarnation, is not limited only to her Divine Son but envelops the entire community of the Church. It develops and becomes present as the history of salvation unfolds. Moreover, as an essential "element" of salvation history, the Virgin Mary becomes more aware of her maternal duties. At Cana in Galilee, she encourages people to obey and do the will of her Son, Jesus Christ (cf. Jn 2: 5), and standing next to the cross, she participates in the saving work of the Redeemer and receives in the 
person of John the maternal protection of all people (cf. Jn 19: 25-27). ${ }^{1}$ Therefore, the work of redemption is inscribed in the Blessed Mary's motherhood.

In other words, Cardinal Wyszyński, presenting the figure of the Blessed Mary, always does it in union with the person of Christ, in partnership with a group of her disciples, that is, in the context of the implementation of God's plan of salvation. By resorting to a particular scheme, it can be assumed that Wyszyński's Mariology emphasizes two strongly interrelated contexts: soteriological and ecclesiological. Within the soteriological context, Wyszyński presents in his teaching the implementation by Christ of the Father's plan in the Holy Spirit. Through the ecclesiological context, the Church's beginnings, in which the Blessed Virgin Mary enacted a significant role.

Moreover, the Marian spirituality of Cardinal Wyszyński may be regarded as essentially of a "praxeological" nature. In this sense, Marian's devotion in Wyszyński's life was practically present from his early childhood. With time, it was deeply rooted in the Christian tradition and passed on through his parents' faith and dedication. Initially, Wyszyński cultivated it because he wanted to be faithful to this heritage. Over time, however, he became convinced that the Blessed Virgin Mary was a real strength both in his life and in the Polish Nation's entire existence. He discovered this truth through difficult events such as the death of his mother, the war with Bolsheviks and the "miracle on the Vistula", through the healing of tuberculosis he had suffered from, through the maternal protection of the Blessed Virgin Mary during World War II, as well as through various other signs that he interpreted in the light of faith.

The appointment to be the bishop, and then the Cardinal and Primate of Poland, presented him with new, extremely tough challenges related to the complicated situation of the Church in Poland, subjected to atheization pressure from the communist authorities. Hence, the period of the Primate's imprisonment was a time of deepening his relationship with Mary. There he made an act of total dedication to the Blessed Virgin Mary in her maternal bondage for the intention of the Church in Poland and the nation. As a result, it created nationwide pastoral initiatives of a Marian character, which were of decisive importance for maintaining the Polish Church's faith and influenced the universal Church as well.

In this context, the most significant Marian pastoral initiatives and events in the life of the Church inspired by Stefan Wyszyński included: "Jasna Góra Vows of the Nation" and the "Great Novena" before the "Millennium of the Baptism of Poland", "Visitation of the Icon of Our Lady of Częstochowa", the act of Marian consecration as an expression of loyalty and trust in her maternal care, applying for the title "Mother of the Church", as well as the election of Karol Wojtyła as a pope, the successor of St. Peter. Thus, it was Pope John Paul II who wrote in a personal letter to Primate: "I have always been convinced that the Holy Spirit called Your Eminence

1 Cf. S. Wyszyński, Matka Kościoła, Watykan 1966, p. 47-59. 
at a unique moment in the history of the Fatherland and the Church, and not only the Church in Poland, but also the entire world. I have looked at this challenging but blessed call since my youth, and I thanked God for it as a special grace for the Church and Poland. I thank [God] for "giving such power to Man" - and I always give thanks for that."

\section{The Blessed Virgin Mary in the Life and Spiritual Formation of Stefan Wyszyński}

The Marian dimension of Stefan Wyszyński's life and ministry was shaped from his earliest youth. He owes his genuine worship to the Mother of God to his parents, who instilled in him the childlike trust and love for Mary, worshiped in their home in the Icons of Our Lady of Częstochowa, "Ostra Brama" as well as Perpetual Help. ${ }^{3}$ He confessed that his parents' attitude and their pilgrimage to Jasna Góra (Częstochowa) and Ostra Brama (Vilnius) “(...) created the foundation for trust and hope for the Mother of God who never left me." ${ }^{4}$ This boundless trust in Mary's love and protection became the guiding signpost in all his ministry. ${ }^{5}$

Indeed, an important experience in his life - as a 19-year-old young man joining the Seminary in Włocławek - was the Polish-Bolshevik war and the Warsaw Battle, the so-called "Miracle on the Vistula", in 1920. Faithful people understood a solemn act of surrender of Poland to the Virgin Mary, Mother of God, made by the Polish Episcopate on 20 July 1920 at Jasna Góra, and then the victory over the Bolsheviks as a blessed sign of the Mother's protection over Poland. ${ }^{6}$

Perhaps this spiritual experience meant that Cardinal Wyszyński attached such a vital role to the act of entrusting the fate of Poland as well as the Church to the Mother of God, believing in their effectiveness. It was the Polish experience of the

2 Dekret o heroiczności cnót Stugi Bożego Stefana Kardynała Wyszyńskiego, https://www. radiomaryja.pl/ kosciol/dekret-o-heroicznosci-cnot-slugi-bozego-stefana-kardynala-wyszynskiego/ [derived: June 14, 2020].

3 Cf. A. Micewski, Kardynat Wyszyński: Prymas i mąż stanu, Paryż 1982, p. 17.

4 S. Wyszyński, Owoce pokornego postugiwania i ufności ku Pani Jasnogórskiej. W 16. rocznice konsekracji biskupiej, Jasna Góra, 12.05.1962, in: S. Wyszyński, Dzieła zebrane, Styczeń - Lipiec 1962, vol. 8, Warszawa 2009, p. 320-321.

5 Talking about his family home, Wyszyński said: “Two paintings hung above my bed in the house: Our Lady of Częstochowa and Our Lady of Ostra Brama. Besides, although I was not inclined to pray at that time, always suffering from my knees, especially during the evening rosary, which was the custom of our home, after waking up, I watched this dark lady and this white lady for a long time. I was just wondering why one is black and the other is white. These are the most distant memories of my past." S. Wyszyński, Kazda prawdziwa miłość z Boga jest. Bachledówka 22.07.1968, in: Kazania i przemówienia autoryzowane 1956-1981, vol. 29, p. 152.

6 Cf. R. Wyszomirski, Maryjna droga kardynała Stefana Wyszyńskiego, "Tarnowskie Studia Teologiczne" 34 (2015), no 1, p. 48-49. 
victory over communism in 1920, on the road to dedication to the Mother of God, that certainly made Mary's promise regarding the victory over communism on the way to giving the world and Russia to her Immaculate Heart was for him something obvious, supported by existential experience.

The Blessed Virgin Mary was present in the life of Stefan Wyszyński through his seminary formation, which culminated in the ordination of the priesthood in 1924. His first Mass, as a priest, he celebrated at Jasna Góra, because - as he said - he wanted "to have a Mother who will always be, who does not die, that she will stand at each of my Masses." Also during subsequent stages of his life, such as pastoral work, studies in Lublin, editorial work in the Włocławek journal "Ateneum Kapłańskie" (Priestly Athenaeum), or the period of World War II, the Marian esteem and worship increased in him. ${ }^{8}$

\section{Our Lady, Mother of God in the Episcopal Ministry of Cardinal Stefan Wyszyński, Primate of Poland}

The episcopal ministry, first in Lublin (1946-1948), and then (from 1949) in Warsaw and Gniezno, the Primate's capital, demanded from Wyszyński extraordinary courage and faith. Faced with the threats and challenges brought by the new political system, communism, he entrusted himself and the whole Nation to the Our Lady of Częstochowa, Queen of Poland and Mother of the Church, many times. Thanks to his brave attitude, Poland and the Church in Poland went through the "red sea of communism" with relatively small losses, compared to other Eastern Block countries "behind the iron curtain".

A significant event characterizing his Marian character became May 12, 1946, the day of the "matrimony" of Bishop Stefan Wyszyński with the Church of the Lublin diocese. In a pastoral letter to the Lublin clergy, on the day of his consecration, he wrote: "I chose as the place of my consecration the capital of the Blessed Virgin Mary in humble faith that her desired mediation would obtain for me the full priesthood and spirit of the High Priest. Through her mediation, let your prayers flow to God's throne."

The newly consecrated bishop adopted the image of Our Lady of Częstochowa in his coat of arms. Under the figure of "Black Madonna", he posted his episcopal

7 Cf. A. Micewski, Kardynat Wyszyński..., op. cit., p. 21. Fr. Stefan Wyszyński celebrated his first mass on August 5, 1924, in Jasna Góra Shrine, at the "Black Madonna" altar. He went there, as he mentioned, that "Maria was always walking ahead of him as a light, life, hope, and supporter under challenging moments. Furthermore, it seems to me that I should put everything on the Mother of God, and I was not disappointed”. S. Wyszyński, Wszystko postawilem na Maryje, Paris 1980, p. 28.

8 Cf. R. Wyszomirski, Maryjna droga ..., op. cit., p. 50.

9 S. Wyszyński, Nie oczekujemy życia łatwego. Podczas ingresu do katedry lubelskiej 26.05.1946, „Wiadomości Diecezjalne Lubelskie” 23 (1946), p. 166 
ministry motto: "Soli Deo". He stated that "[...] this coat of arms is not an ornament; it is not just a sign. It is the program of my episcopal and Primate's mission. ${ }^{10} \mathrm{~A}$ couple of months later, Wyszyński wrote: "In my opinion, «Soli Deo» is not a simple decoration of the episcopal seal. In my opinion, it is a program that has been shaped in the face of the overpowering invasion of hatred and unbelief in our homeland and the Holy Church in Poland. This program was later supplemented with what is so dear to me: Per Mariam." 11

Stefan Wyszyński, as a bishop of the Lublin diocese, was convinced of the significant role of the Marian devotion. This idea was reflected in pilgrimage to sanctuaries and he devoted much attention to the shrines in his area. In July 1946, he reconstructed the "Mother of God" icon in Chełm, combining this celebration with the Act of Consecrating Poland to the "Immaculate Heart of Mary". During twenty-seven months of service in the diocese of Lublin, he also visited the Marian shrines in Krasnobród, Janów Lubelski, Radecznica, Puławy, and Tyszowce. ${ }^{12}$

The Cardinal surrounded a unique devotion of the copy of the Jasna Góra icon located in the Lublin cathedral. Moreover, he sought to coordinate pastoral service in sanctuaries, propagated the spread of rosary prayer in families, and organized rosary congresses at several shrines. As a bishop, he sought to revive the activity of "Marian Sodality", which was created to shape the apostolic attitude not only of their members but also the entire diocese. On November 5, 1949, he established the "Institute of the Rosary Apostolate", which had become a part of the "Pastoral Department" of the Episcopal Curia. ${ }^{13}$

Interestingly, when Bishop Wyszyński accepted the position of the Primate of Poland, he did not have a "real" program of pastoral ministry in Poland. This plan was created spontaneously, conditioned by the conviction of Mary's presence in the life of Christ and the Church. It resulted from the Primate's personal experiences and the experience of Mary's active power in his life and nation, as well as reading the signs of the times in a difficult socio-political situation in the country. ${ }^{14}$

Nevertheless, the nationwide Marian initiatives were officially announced in principle as undertakings of the Polish Episcopal Conference, served by the Marian Commission, established in December 1956, and cooperating with the General Pastoral Commission, which worked out an outline of specific pastoral actions. The chairmen of the Commission were mostly bishops of the Częstochowa diocese: Bishop Zdzisław Goliński, Bishop Stefan Bareła, and Archbishop Stanisław Nowak (however, in the years 1963-1966 the chairman of the Commission became Bishop

${ }^{10}$ S. Wyszyński, Nie oczekujemy..., op. cit., p. 170-171.

${ }^{11}$ S. Wyszyński, Wszystko postawitem..., op. cit., p. 19.

${ }^{12}$ Cf. B. Pylak, Stefan Wyszyński biskup lubelski, Lublin 1999, p. 28-37.

${ }^{13}$ Cf. R. Wyszomirski, Maryjna droga ..., op. cit., p. 52.

${ }^{14}$ Cf. A.F. Dziuba, Polityczny wymiar aktywności chrześcijańskiej w nauczaniu Księdza Prymasa Stefana Wyszyńskiego, in: Nauczanie spoleczne Kardynała Stefana Wyszyńskiego, eds. A. Garbarz, Rzeszów 2001, p. 45-94. 
Antoni Pawłowski from Włocławek, and - in 1984-1989 - Bishop Bolesław Pylak from Lublin).

Regardless of this, Primate Wyszyński himself chaired the assemblies of the Commission many times. Usually, 14-20 people attended the Committee meetings, including laymen who were generally represented by members of the "Institute of Nation's Vows". The contribution of this Commission in shaping the Marian pastoral program requires a separate study. Nevertheless, from experience and deep conviction, many pastoral plans were born there - also, many initiatives related to the Marian cult, which were consistently implemented into pastoral reality. Primate Wyszyński's initiatives overlapped and complemented each other to a large extent. In a sense, they were inspired by subsequent anniversaries. One of them was the upcoming one-thousandth anniversary of the baptism of Poland. ${ }^{15}$

In other words, the Marian dimension of the spirituality of Primate Wyszyński was part of a long-term pastoral program consisting of uniting the Nation around the Gospel, the cross, the Church, and the worship of Our Lady the Queen of Poland. This program's essence was based on Mary's recognition as the Queen of Poland and Mother of the Church. The next stages of this program were: Jasna Góra Vows of the Nation (1956), peregrination of the Ikon of Our Lady of Częstochowa through the Polish dioceses and parishes (from 1957-1966), the Great Novena before the Millennium of the Baptism of Poland (1957-1965), and, mostly, the celebration of the Millennium of Christianity in Poland in 1966 combined with the solemn "Act of Dedication of Poland to Mary Mother of the Church for the freedom of the Christ Church" (May 3, 1966). ${ }^{16}$

\section{The Blessed Virgin Mary, Mother of the Son of Man: Basic Anthropological and Theological Notions}

Contemporary theology points out the importance of Mariology's anthropological and theological dimension as a part of ecclesiology. Moreover, it is kept on by combining Mariology with Christology, pneumatology, and other treatises of theology. In other words, the anthropological and theological context allows us to conduct a deeper contemporary Mariological reflection. Hence, faithful people can find in Mary a model and hope. In other words, in Mary's figure, one can see the Christian vision of the human person. Uniquely, therefore, Mary is the model of a woman as well as the archetype of a "New Man in Christ". However, the most essential is her deep spiritual relationship with the Son, readability of the personal response of human freedom, the maturity of faith, the perfect harmony of nature as well as grace, and, above all, participation in the salvific mission of her Son.

${ }^{15}$ Cf. R. Wyszomirski, Maryjna droga ..., op. cit., p. 52.

${ }^{16}$ Cf. Akt oddania Polski w macierzyńska niewole Maryi, Matki Kościoła, za wolność Kościoła Chrystusowego, Jasna Góra, 3 maja 1966, in: Matka Odkupiciela Matka Kościota. Dokumenty, eds. A. Wieczorek, Warszawa 1990, p. 30-31. 
In his reflections, Cardinal Wyszyński emphasizes that man needs the "ideal" so that he can believe that it is worth making efforts to struggle with himself, fight the effects of original sin, harmonize what is broken, and, seemingly, incompatible. We need an Ideal that would stand clear to a man and which he would always desire. Therefore, a man must have a model that would give him a spirit and awaken his ambition and not let him give in to inaction and discouragement. In this context, the Virgin Mary, Mother of God, points out that all is not lost and can make an effort to repair one's life. ${ }^{17}$

The Primate exposes the faithful to a double blessed pattern: Christ and Mary. ${ }^{18}$ For him, the contemporary priesthood should also be a ministerial priesthood, following the example of the Handmaid of the Lord. It means that sometimes we will have to suspend our judgment to submit to God's thought and His Providence. Sometimes we have to know how to wait and trust and trust in a seemingly hopeless situation. We may have to go through the fire and water of criticism, accusations, slander, or sophisticated attacks. ${ }^{19}$

As a result, the Primate points out the Blessed Mary to the consecrated persons as an example. In the Mother of God, therefore, one can discover what spousal life with Christ and for Christ is. As a Blessed Virgin at the heart of the Church, she leaves the perfect model of the spiritual formation necessary to serve Christ in sincere mystical devotion.

Thus, the Blessed Mary, the Mother of God, is also the perfect model for Catholic parents, fathers, and mothers. Just as for Mary, Jesus is the blessed fruit of her life, so for parents, the blessed fruit of life is their children. In this sense, the Blessed Mary's motherhood reveals the dignity of every motherhood. Spouses, bound by the sacrament, are called to preserve the great dignity of marriage and participate in the transfer of life, care for a fit and healthy life, raise a child, and, above all, by their own example, to sanctify each other. In this context, the Cardinal exposes the first family's recapitulation (Adam and Eve) and the Holy Family. In this sense, the Blessed Mary is not only a moral model of the family but also a grace granted to all families: she is the one who, in the Holy Family, "distributes" Christ to the people. The Mother of Christ, defending the unborn child's life from the "evil dragon", is a service model to life. It shows the way to parents, doctors, nurses, and health care workers. Therefore, She should be "the patron of all clinics where young Poland is born." 20

It is Marian spirituality that makes Christian culture a culture of woman's praise. To this praise, after Mary, the woman responds with an attitude of service. She serves persistently not only at home and in the family but also at work and social activities.

17 Cf. S. Wyszyński, Rozważania o Matce Boga-Człowieka, Jasna Góra 1983, p. 53-59.

18 Cf. S. Wyszyński, Matka Syna Człowieczego, Poznań 1984, p. 133.

19 Cf. S. Wyszyński, Wszystko postawiłem ..., op. cit., p. 32.

${ }^{20}$ Cf. S. Wyszyński, Nie gaście ducha ojca Maksymiliana, Niepokalanów 1996, p. 164. 
She tries to fulfill these significant tasks as understood as implementing God's program, with courage and humility.

In the Blessed Mary, Our Lady of Sorrows, standing under the Cross of Her Son (Mater Dolorosa), Cardinal Wyszyński sees a symbol of courage, which male representatives often lacked. Thus, she emphasizes women's persistence, loyalty, and patience in difficult times in the Church's history. Therefore, the Virgin Mary and Mother remain an excellent model and ideal for the modern female world, showing how to enrich public, social, economic, and cultural life. The growing influence of women brings hope for a revival of culture. However, this will happen when women would not forget about the high value of feminity and motherhood. ${ }^{21}$ "Thanks to Mary, deep respect for our sisters and every woman develops. It would continue in Poland that motherhood's dignity would not be humiliated and that girlish nobility would be respected. In this sense, the Mother's faith is essential to the entire family. Even if the husband and children do not believe, the mother can give them faith and hope."22

Moreover, as Wyszyński states, the Blessed Virgin Mary is the Mother of Beautiful Love because God's own salvific plan preserved her from any stain of sin. Thus, the Blessed Mary is a model of holiness for the People of God. According to the Primate, a believer who creates the structure of the Church and seeks a model for his Christian identity in the Church can, therefore, base his efforts on the style of Mary's life. Thus, the Church, bearing in mind the unique role of Mary as a woman, speaks about the dignity and vocation of women in family, social and Church life; defends the concept of marriage as a union between a man and a woman; it helps families, especially large families and single mothers. Here is a message in Mary's spirit, which, respected by believers, practically inspires to act in the service of life and every human being's dignity.

As the "Handmaid of the Lord", the Blessed Virgin Mary is a model as well as a sign and icon of God's gift and thus a sign that attracts everyone to accept and preserve the gift of holiness, only secondarily, she is an example of cooperation with grace. However, holiness is a gift and a task, a grace given freely and the result of human collaboration with it. In this sense, Blessed Mary touches with her life the existential dimension of every Christian's life. The mystery of her presence in the work of salvation and calling her to be the Mother of the Son of God and the Mother of all believers in the Mystery of the Church leads the Church herself to the very important existential problem of dignity and respect for human life from conception to natural death. ${ }^{23}$

From the option of respecting human life arises the Church's view of temporality as the time and place of preparation for eternal life. It is expressed, among other

${ }^{21}$ Cf. S. Wyszyński, Matka Kościoła, p. 37-38.

22 S. Wyszyński, Godność kobiety, Warszawa 1998, p. 81-83.

${ }^{23}$ Cf. S. Wyszyński, Rozważania o Matce..., op. cit., p. 68-74. 
things, in treating the day of death as the day of birth into a supernatural "reality", birth to full participation in the glory of Heaven, initiated in temporality through the faith and sacraments of the Church. Bearing in mind the arguments presented here, the Church opposes all phenomena of the "civilization of death" that pose a threat to a human being. Moreover, the Church professes and proclaims the "Gospel of Life" following the example of the one who brought life to the world: the life that remained in the service of man, ensuring his salvation and eschatological fulfillment.

\section{The Blessed Virgin Mary as a Mother of the Church: Creative-Salvific Perspective}

Stefan Wyszyński reminds us that Christ left us the Mother for an important reason. She is a help, a hope in the time of darkness, in an awkward moment when all support is lacking. ${ }^{24}$ "There is no such word as 'impossible' when the Blessed Mary, who first believed in the 'impossible', leads and supports." ${ }^{25}$ The philosophy of hopelessness, unbelief, and indifference must be contrasted with the philosophy of hope, life, and faith. God displays it in Mary; she is humanity's rescue. In the Assumed Mary, the Woman clothed with the sun, the author sees a unique sign of the hope so needed by the modern world.

The Blessed Mary's mission is to give people a God-Man so that man can discover his high dignity as a child of God ${ }^{26}$ Mary's extraordinary human dignity results from a dedication of the whole-person to Christ; Mary is all for Christ. ${ }^{27}$ She exposes dignity in suffering, and she remains under the cross with calmness. Moderation and peace are characteristic of her behavior, and this behavior corresponds to her soul.

According to the Cardinal, there is a connection between Marian piety and the recognition, as well as the respect, of human dignity. Connected with the will of the cross, we hear Mary's words at the threshold of the new Millennium calling for the fulfillment of the will of her Son (Jn 2, 5). She invites us above all to what results from our humanity, from our great dignity of the human person, from the dignity of God's child. This dignity is so great that we do not lose it even when we feel the weakness of our fall the most painfully, even though we are still the children of the greatest Love. ${ }^{28}$

The teaching of the Primate emphasizes the anthropological and theological aspects of the mystery of the Immaculate Conception. Distrust of God, which was the essence of original sin, had distorted the harmony between body and soul. The Blessed Mary harmonizes the material and spiritual elements in people again. In Mary,

${ }^{24}$ Cf. S. Wyszyński, Miłość miłosierna, Warszawa 1998, p. 67.

25 CF. S. Wyszyński, Kromka chleba, Warszawa 2008, p. 63.

26 Cf. S. Wyszyński, Do Solidarności. Rady i wskazania, Warszawa 1996, p. 7.

27 Cf. S. Wyszyński, Rozważania o Matce..., op. cit., p. 94.

${ }_{28}$ Cf. S. Wyszyński, Na drogach zawierzenia, Warszawa 1996, p. 140. 
God reveals that it is possible to reconcile man with God, restore harmony between the rights of "corporal reality" and spirit, and obtain internal peace as well as joy. ${ }^{29}$

In this context, Stefan Wyszyński points to the importance of the human body of Mary in God's plan of salvation and the resulting relationship of the Blessed Mary with the Sacrament of the Eucharist: "God needed a Mother (...) He needed Her immaculate body, Her blood, milk Her "breast from the heavens filled", Her arms and Her maternal care in her clumsy childhood. It was she who gave him the Immaculate Body, which he took to the Father on the cross and the altar of the world. She gave him blood for the Calvary Sacrifice and the chalices." 30

Marian piety responds to the human need of the Mother, who is close to us and understands our human reality. ${ }^{31}$ In this context, the Primate attempts to bring us closer to the extraordinary nature of the Blessed Heart of Mary, filled with love and compassion for all lost humanity. We can see her sensitivity to human suffering and misery. Mother of God has extraordinary mercy because she can be approached carefully, understands everything, is not offended, and does not reject anyone. The children of Fatima, simple people, the poor, are drawn to her. ${ }^{32}$ Thus, the Cardinal encourages us to imitate the Blessed Mary's sensitivity to learn from her delicacy and gracefulness towards other people. We should notice her tenderness and sensitivity. It draws attention to what it does not see and even trampled by the big world. ${ }^{33}$

In the text of the "Jasna Góra Vows of the Polish Nation", Cardinal Wyszynski wanted to submit to the Blessed Mary all the work undertaken by Poles: "We put at Your feet ourselves and everything we already have: our families, temples and houses, field plots and workshops, plows, hammers and feathers, all efforts our thoughts, tremors of hearts and gusts of will." ${ }^{34}$ A look at the Blessed Virgin tends to glimpse the theological meaning of earthly realities, and especially human work. Stefan Wyszyński, therefore, draws attention to the existence of the Mother of God filled with everyday hardship. ${ }^{35}$

During the "Solidarity" breakthrough, the Cardinal entrusted to the Blessed Mary the desire that human work in Poland refine and sanctify, that not only the objects of human labor but also man, through his daily efforts, become better and better, that social changes in Poland would lead to the ennobling of a respected human person and God. ${ }^{36}$

By looking at the spirituality of the Mother of God, the reality of authentic human freedom was deeply emphasized. The Blessed Mary is free from the original

${ }^{29}$ Cf. S. Wyszyński, A była tam Matka..., Warszawa 2001, p. 12.

30 S. Wyszyński, Gody w Kanie, Paris 1962, p. 13.

31 Cf. S. Wyszyński, Dzieła zebrane, vol. 5, 1959, Warszawa 2006, p. 223.

32 Cf. S. Wyszyński, Gtos z Jasnej Góry, Warszawa 1984, p. 32-34.

33 Cf. S. Wyszyński, Miłość na co dzień. Rozważania, Warszawa-Ząbki 2001, p. 35.

34 S. Wyszyński, Rozważania o Matce..., op. cit., p. 97.

35 Cf. S. Wyszyński, Na drogach zawierzenia ..., op. cit., p. 19.

${ }^{36}$ Cf. S. Wyszyński, Do Solidarności..., op. cit., p. 7. 
sin of her first parents. Moreover, Mary's consent at the Annunciation is prudent, rational, and, therefore, completely voluntary. Mary's action is completely free. The Church fathers of the first centuries of Christianity, comparing Eve and the Blessed Mary, emphasized the active, conscious, and voluntary cooperation of the Blessed Mother's life with God's plan. ${ }^{37}$ In Mary's example, hence, Cardinal Wyszyński points out that authentic love is not expressed in declarations but in a real-life full of concern for another person. The Blessed Virgin Mary, the Mother of God, is present not only at the altars but in all our circumstances, troubles, hardships both in personal problems and in the significant issues of the entire Church. She is present with every bishop, priest, religious person, and every family. She touches everything in detail. Therefore, the Blessed Mary, following in the footsteps of the incarnate God, somehow in a mystical way "incarnates" in our lives and the life of the Church.

\section{Primate's Marian Pastoral Program: Soli Deo per Mariam}

Although the essentially Marian dimension of the life and pastoral ministry of Cardinal Wyszyński was associated with the worship of Our Lady of Częstochowa, it is not difficult to notice that he was also open to the signs of the times, especially to the Fatima apparitions. As a great venerator of the Blessed Virgin Mary, he wanted to be the messenger of Marian providential presence in the history of salvation. Therefore, he called for a similar response from popes and bishops from around the world, as well as, the Polish Nation, entrusted to his pastoral care.

In this sense, "Jasna Góra Nation's Vows" proclaimed on Jasna Góra on August 26,1956 , remain a prophetic document as well as an event deeply inscribed in the history of post-war Poland. For nine years, they constituted the pastoral program of the Church in Poland. Therefore, the Primate of Poland prepared a full pastoral program based on piety and Marian reverence in connection with the upcoming $300^{\text {th }}$ anniversary of the vows of Jan Kazimierz in the perspective of preparing the Church in Poland for the celebration of the Millennium of Christianity. ${ }^{38}$

Nevertheless, the specific promises made in the "Jasna Góra Vows of the Nation" in this case were not to remain empty words. However, they were to be developed in the following years in the form of "National Retreats" understood as a part of the

${ }^{37}$ Cf. S. Wyszyński, Matka Kościoła, op. cit., p. 12.

${ }^{38}$ On the $300^{\text {th }}$ anniversary of these vows, which - genuinely speaking - were never fully completed, the Primate wanted to refer to them and adapt the new vows of the Nation to the present day: "In their main warp, the Jasna Góra Vows follow the line of Jan Kazimierz's unfulfilled Royal Vows. However, they are developed and adapted to new needs. They are formulated so that it is to be filled not by the "elite", but by the entire Nation. While the king was obliged in Lviv, the whole Nation committed itself to Jasna Góra. There is no king - but the Nation remains" s. Wyszyński, Pracujemy wszyscy nad wprowadzeniem w życie Ślubów Jasnogórskich, in: S. Wyszyński, Wszystko postawilem na Maryję, Paris 1980, p. 117. 
"Great Millennium Novena". And what was this "Novena"? A grand celebration of the Millennium of the Baptism of Poland was planned for 1966. Primate Wyszyński did not treat this anniversary only as a pretext to organize the tremendous and solemn church-patriotic celebrations. It was not supposed to be one of a series of more extensive "demonstrations" under the patronage of the Polish Episcopate as well.

On the contrary, Cardinal Stefan Wyszyński set himself the task that the Nation should enter the new millennium of Polish Christianity religiously renewed - spiritually and morally reborn. Nevertheless, the Polish Church had to be prepared for this. According to Wyszyński plans, it was supposed to take nine years. ${ }^{39}$ Therefore, the Great Novena consisted in the annual deepening of one issue to introduce the "Vows of Jasna Góra" into the faithful's daily life and prepare the entire community for the Millennium of the Baptism of Poland. The Primate demanded mighty work from other bishops and priests. Sermons and speeches were given, conferences and catecheses were organized; however, the entire "program" had required "going down" to the ordinary people. ${ }^{40}$

The essence of all this pastoral work was that it was directed to everyone, not to any particular social or age group. There was then, as one says today, no "target group". This "target group" was the entire nation and each individual, regardless of gender, age, profession, or even attitude towards the Church. And although the Church in her undertaking was a conscious "sign of opposition" to the then prevailing atheistic ideology of "real socialism", the Marian pastoral program was not directed against people in power, nor did it exclude them. The main message of the "Jasna Góra Vows", the "Great Novena", and the "Millennium of the Baptism of Poland" was simple. It concerned the basic principles of faith, morality, and Catholic tradition. Of course, when working with different people, the topics were explored in a way adapted to each group, but the main and primary message was uniform and universal. ${ }^{41}$ As Wyszyński pointed out: "The essence of the 'Great Novena' is a work

39 It was a pastoral program planned for 1957-1966, preparing Polish people to celebrate the "Millennium of the Baptism of Poland". The "Great Novena" was, in fact, the first integral nationwide program aimed at reviving all areas of pastoral care throughout the entire country. Cf. B. Nitkiewicz, Jasnogórskie śluby narodu: milenijne zobowiąanie na dzisiaj, Wrocław 2016.

40 Karol Wojtyła, who at that time was a bishop in Krakow, later recalled: "And then all of us, all Polish bishops, we learned our homeland. We learned, one by one, all the Polish dioceses" (Jan Paweł II, Homilia podczas Liturgii Słowa przed kościołem Pierwszych Męczenników Polskich,Gorzów Wielkopolski, 2 VI 1997 r., in: http://nauczaniejp2.pl/ dokumenty/ wyswietl/id/428/pos/3/haslo/ m\%C4\%99cze\% C5\%84stwo,\%20m \%C4\%99 czennicy, [derived: November 21, 2020].

41 The program of the "Great Novena" was implemented in the following years around the subsequent catchphrases:Year I. 1957/58: "Fidelity to God, the Cross, the Gospel, the Church, and her Shepherds";

Year II. 1958/59: “A Nation Free and Faithful to grace”: living in God's grace and resisting every sin; 
of spiritual transformation based on God's grace. The point is that at the Millennium we should have God's people, who live their daily life by sanctifying grace, united with Christ, rooted in the Mystical Body of the Holy Church, reborn in their family and social life." $" 42$

Thus, the "Jasna Góra Vows" were to combine the religious idea with the notion of the nation. This relationship, characteristic of Polish people through the ages, was to pass the exam in a challenging era. Therefore, the subject was to be the entire nation. After the solemn Vows, which on August 26, 1956 millions of faithful gathered, the Primate, remaining in seclusion, wrote in Komańcza: "These people testified that the Queen of Poland is the most popular figure in the life of the Nation. It turns out that the influence of Jasna Gora on the life of the Nation cannot be reduced to a shallow devotion. It turns out that Jasna Góra is an internal binder of Polish life. It is a force that grasps deeply at the heart and keeps the whole Nation in a humble and firm attitude of loyalty to God, the Church, and her hierarchy. The Queen of Poland leads the Nation to her Son and His Church." ${ }^{\text {43 }}$

The Jasna Góra Vows, next to the introduction referring to the vows of Jan Kazimierz and the end of the binding oath with preparation for the Millennium, also comprised a religious-moral-social content. They emphasized remaining faithful to God, the Church, and her pastors, staying in sanctifying grace, respect for the gift of life, indissolubility of marriage, dignity of a woman, and saturation of family life with principles of the Gospel. They highlight the defense of the young generation against unbelief and moral corruption, social agreement, peace, and love as well as the equitable distribution of goods, the fight against national vices and the development of social virtues, and the spread of worship for the Mother of God in the Fatherland. ${ }^{44}$ Thus, they remain a program of the new socio-political order permanently. In

Year III. 1959/60: "Life is the Light of People": A year of life, defense of life, soul and body;

Year IV. 1960/61: "Marriage - a great sacrament in the Church";

Year V. May 1961/62: "The Family is Strong with God" - education in the spirit of Christ; Year VI. 1962/63: "Youth Free and Faithful to Christ";

Year VII. 1963/64: "Love Each Other Socially" - social justice and love;

Year VIII. 1964/65: "New man in Christ" - fighting against national defects, cultivating Christian and national virtues;

Year IX. 1965/66: "Take Care of the Whole Nation" - Honor the Blessed Mary as the Queen of Poland. Cf. J. Zawadka, Wielka Nowenna w koncepcji duszpasterskiej Prymasa Wyszyńskiego. Zarys problematyki pastoralno-historycznej, „Warszawskie Studia Teologiczne" 24 (2011), no 1, p. 243-254; J. Lewandowski, Wychowawcze aspekty Wielkiej Nowenny w nauczaniu Kardynała Stefana Wyszyńskiego, „Chrześcijanin w Świecie” 116 (1983), no 5, p. 9-30.

42 S. Wyszyński, Ustóp Patronki polskiej młodzieży akademickiej, Jasna Góra (10.05.1959), in: S. Wyszyński, Uświęcenie pracy zawodowej, Paris 1963, p. 146.

43 S. Wyszyński, Pracujemy wszyscy..., op. cit., p. 134.

${ }^{44}$ Cf. Akt oddania Polski..., op. cit., p. 30-31. 
other words, they mobilize Catholic society to live by Christian values. Moreover, personal vows concern successively individual, family as well as social life.

"The Polish Nation has already made its Vows many times. Although it has maintained faith in the Church, however, it had not got rid of many addictions and national vices that are incompatible with the faithful Nation's attitude. Fight this split, gain a moral division, learn to win ourselves, gain bravery of faith and Christian life - this is the blessed pursuit of almost conservative national instinct and the Catholic gist." ${ }^{25}$

\section{The "Great Marian Novena" and the "Millennium of Baptism of Poland": Towards Moral Renewal of Man and the Nation}

To understand these activities' specifics, one needs to go back to the events that took place on August 26, 1956. On this day, on the solemnity of Our Lady of Częstochowa, the square under the Jasna Gora Sanctuary's summit and the Blessed Virgin Mary's Avenue leading to it in Częstochowa was tightly filled with pilgrims. To this day, historians are not sure how many there were. According to the estimated calculations of the chronicler from Jasna Góra, there were more than a million pilgrims. According to official data, almost 600-650 thousand people.

However, at the confidential meeting of the "Communist Party Central Committee", Zenon Kliszko - one of Gomułka's most trusted associates - talked to about 1,4 million people. The culminating moment of the ceremony in Częstochowa was the "Jasna Góra Vows of the Nation". The celebrations took place two months after the workers' rebellion in Poznan, which was directly caused by the Cegielski factory's protest (then named after Joseph Stalin) against unfair payroll calculation. However, the workers demanded not only better wages. They wanted "bread and freedom", as well as the right to God.

The liturgical ceremony at the Marian Shrine began at 10 in the morning. A "Miraculous Icon" of Our Lady of Częstochowa was brought to the Jasna Góra embankment. Twenty-eight bishops, seven capitular vicars, and over 1,500 priests stood at the altar. Bishop Michał Klepacz read a telegram from Pius XII blessing the Polish people. However, there was no Cardinal Wyszyński. He was still in prison. An empty throne with the Primate's coat of arms was a reminder of this. Many white and red roses lay on the armchair as a symbol of spiritual communion with the Primate. Undoubtedly, the empty armchair, which symbolized the demand for the presence of Cardinal Stefan Wyszyński, had made the most significant impression on people. ${ }^{46}$

45 S. Wyszyński, Pracujemy wszyscy..., op. cit., p. 136.

${ }^{46}$ Cf. R. Ficek, Christians in Socio-Political Life. An Applied Analysis of the Theological Anthropology of Cardinal Stefan Wyszyński, Primate of Poland, Toruń 2020, p. 285-287; J. Krukowski, Stanowisko Prymasa Stefana Wyszyńskiego w sprawie normalizacji sytuacji prawnej Kościoła w Polsce, ,Roczniki Nauk Społecznych” 10 (1982), p. 59-75. 
This symbolic scene with an empty armchair would be repeated twice more in the history of Poland. The first time, ten years later, on May 3, 1966, when the communists did not allow Pope Paul VI to come to the millennium celebrations in Jasna Góra shrine. The empty throne waiting for the pope was an unusually eloquent commentator of those events. For the third time, an unoccupied armchair stood not on the Jasna Góra ramparts, but Krakow Błonie in 1999. At that time, over a million people prayed in the rain for health for John Paul II, who could not say the Pontifical Mass because of infection. ${ }^{47}$

The "Jasna Góra Vows", "Great Millennium Novena," and "Millennium of the Baptism of Poland" constitute a whole that has played an invaluable role in the recent history of the Church in Poland. However, it was characterized both by baptismal and Marian dimensions. The baptismal aspect because this program was inspired by the millennium of the baptism of Poland. And baptism as a sacrament having a renewing power. Each individual was to recall his/her baptism and, in this spirit, strive for constant conversion and "putting on Christ". The whole community was also to be renewed, in a spirit of reconciliation and forgiveness, remembering the baptism of Poland in 966. It is no coincidence that in 1965, a year before the "Millennium of the Baptism of Poland", the Polish Episcopate addressed his famous letter to the German bishops, in which it forgives and asks for forgiveness. ${ }^{48}$

Moreover, a strong Marian accent accompanied all these actions. The "Great Novena" before the Millennium of Polish Christianity is Marian in terms of both its origin and essence. It is a "Novena to Our Lady, Mother of God", a collective prayer for fidelity to grace and a seminary of moral life. The "Great Novena" was accompanied by the pilgrimage of a copy of the icon of Our Lady of Częstochowa throughout Poland. It was this courageous pastoral program of Stefan Wyszyński that prepared the ground for everything that would have happened later - the preparation for the second stage of work started by John Paul II, when in 1979 in Warsaw he uttered the famous words: "Let Your Spirit descend and renew the face of the earth, this earth". In this sense, John Paul II was also shaped by these events as a Shepherd of the Church. There is no doubt that he drew from these experiences when he had brought the entire Catholic world into the third millennium of Christianity.

After returning from imprisonment (October 28, 1956) in Komańcza to Warsaw, and then, after a pilgrimage to Częstochowa/Jasna Góra (November 2, 1956), the Primate supervised the implementation of the "Vows Program". On Sunday, May 5, the following year (1957), the "Jasna Góra Vows" were renewed in all parishes, rectoral churches, and monastery chapels. They entered, or instead constituted, the Great Novena pastoral program before the Millennium of Poland's Baptism (19571966). The following years were devoted to individual refrains of the Vows, which

${ }^{47}$ Cf. E.K. Czaczkowska, Kardynat Wyszyński: Bibliografia, Kraków 2013, p. 244-247.

${ }^{48}$ Cf. P. Madajczyk, Orędzie biskupów z 1965 r. jako element obchodów mileninych, „Więź” 145 (1997), p. 144-151. 
were ceremonially repeated at Jasna Góra on May 3, on the solemnity of Our Lady the Queen of Poland, and in parishes the next Sunday after the ceremony. ${ }^{49}$

Primate Wyszyński very often referred to the social content of the Jasna Góra Vows. Faced with state censorship against the Jasna Góra Vows program, and not even consenting to print the text of the Jasna Góra Vows of the Nation, the Primate was convinced of the need to form in their spirit a new generation of devotion that grew after the celebration of the Millennium of Christianity in Poland. Therefore, together with the Polish Episcopate, Wyszyński pointed out that the second year of preparation for celebrating the $600^{\text {th }}$ anniversary of the Jasna Gora shrine should be devoted to the "Jasna Góra Vows" of the Nation.

Cardinal Stefan Wyszyński reminded the aation of the Jasna Góra Vows at the Jasna Góra shrine many times. On April 30, 1977, in the context of the struggle for human rights, the Primate said: "The obligations contained in the 'Jasna Góra Vows' are the responsibility of each of us; they are the responsibility of the family, nation, state, and all authorities that the state uses. There can be no institutions that violate fundamental human rights in any way. Today, international agreements guarantee this, but the obligation to respect human rights comes first from the spirit of the Gospel. In our homeland, however, it also flows from the spirit of Christian culture, which we lived and live. Social obligations arising from the Jasna Góra Vows are connected not only with the Jasna Góra Vows but with all our culture, native and national, which must come to the fore for the Nation to live in harmony and peace, without violation or oppression." 50

The idea of Vows, as well as their significance for the life of the Church and Polish society, were also known from the personal experience of Cardinal Karol Wojtyła. As a Pope, John Paul II called them the "Polish Charter of Human Rights." On various occasions, he had reminded the Church in Poland of the Marian path marked out by Cardinal Stefan Wyszyński.

\section{Conclusions}

To be sure, Cardinal Wyszyński's teaching contains views and interpretations primarily original, vivid, and characteristic of the centuries-old Polish Marian spirituality, which can also serve the universal Church. Nevertheless, Wyszyński's outstanding

49 The culminating moment on the Marian way of Cardinal Wyszyński's service was the act of total dedication to the Blessed Mary ever Virgin in the spirit of St. Louis Maria Grignion de Montfort. The pastoral programs that emerged as a consequence of this Vow played a decisive role in maintaining the faith and Christian tradition by the Nation, strengthening the post-war Church in Poland, and impacted the entire universal Church as well. Cf. S. Wyszyński, Wszystko postawitem ..., op. cit., p. 39-47.

50 S. Wyszyński, Kultura zaczyna się pod sercem matki ... Słowo na zakończenie Tygodnia kultury chrześcijańskiej. Warszawa - kościót św. Anny 30. 04. 1977, in: Kazania i przemówienia autoryzowane 1956-1981, vol. 57, Warszawa 1981, p. 214. 
achievement is to overcome the ecclesial antinomy and Mariology present in Polish theology and spirituality by looking at both treatises (Ecclesiology and Mariology) from one point of view, it means by relating them to Christ. It is predominantly expressed in the "dual treatment" of the Blessed Mary's Motherhood and the Church towards Christ (Mary-Mother; Church-Mother).

According to Wyszyński, the Blessed Mary and Church relations find a foundation and a point of reference in Mary's maternal function towards the Son of God as the Founder and Head of the Church. Thus Mary's Motherhood extends to the Body of Christ, which is the Church. From this maternal function of Mary towards Christ, he also draws the teaching about Mary as the prototype of the Church in the order of faith, love, and union with Christ. In considering Mary and the Church's relations, Cardinal Wyszyński emphasizes Mary's "presence" in the Church's mystery. Mary is present in the mystery of the Church as she was present in the mystery of Christ, i.e., cooperating in the mystery of Redemption. Now, she collaborates in leading the Church of Christ to the Father and in realizing the mystery of Redemption.

Teaching Card. Wyszyński on the relations between Mary and the Church has a praxeological character and is reflected in his vision of pastoral ministry, where Mary plays a fundamental role and always does so in the context of the Redemption. Through the act of obedience to the revealing God, Mary entered into a mysterious union with Him and joined herself with God's redemptive love with the desire to redeem all humanity. For the Blessed Mary, her obedience is a subjective and prior acceptance of Christ's salvation; it is her salvation in Christ. The free acceptance of motherhood as a gift of God was accomplished in Mary thanks to her faith. Ever since Mary believed, since faith became her blessing, she has guarded our faith - the faith of the Church. In this context, the Primate broadens the interpretation of the parallel: Eve - Mary and believes that, as God in salvation contrasted Mary's faith with Eve's unbelief and doubts, this opposition applies not only to Eve but also to all those who succumb to doubts and unbelief.

In his episcopal ministry, Cardinal Wyszyński often referred to numerous Marian pastoral initiatives, especially the "Jasna Góra Vows of the Nation". In her reflection on faith, Mary is a motivation for believers to worship the Triune God who has done "great works" through her person. Moreover, all Marian pastoral initiatives fit into the perspective of God's economy of salvation. Mary participates in this economy through her virginal motherhood. In other words, Mary continually transfers the work of Christ to the level of the Church in an effective and universal way. In this way, Christ's merciful and saving power is expressed through Mary, currently present in the Church. Mary gives the presence of her Son in the Church a unique and irreplaceable tint of her person, whose characteristic feature is motherhood.

In this sense, the Church participates in Christ's realization of salvation hic et nunc; it is a continuation of the salvific process that the Mother watches over as she has watched over it in the mystery of Christ. Mary's active presence in the Church for Wyszyński winds up giving her the title of "Mother of the Church". As the ideal 
of man created in the image and likeness of God, Mary was destined to be the Mother of the Incarnate Word, kept in the mystery of spiritual beauty from contamination by the effects of original sin, helps to discover the truth about the mystery of human freedom, salvation, and eschatological fulfillment. Therefore, Mary is the image of every human being renewed by the saving power of Christ, and she is also the model of a call to holiness, both individually and for the entire universal Church.

\section{References}

\section{Internet sources}

Dekret o heroiczności cnót Stugi Bożego Stefana Kardynała Wyszyńskiego, https:// www.radiomaryja.pl/kosciol/dekret-o-heroicznosci-cnot-slugi-bozego-stefana-kardynala-wyszynskiego/ [derived June, 14, 2020].

Jan Paweł II, Homilia podczas Liturgii Stowa przed kościołem Pierwszych Męczenników Polskich, Gorzów Wielkopolski, 2.06 .1997 r., http://nauczaniejp2.p1/ dokumenty/ wyswietl/id/428/pos/3/haslo/ m\%C4\%99cze\% C5\%84stwo,\%20m $\%$ C4\%99 czennicy, [derived: November 21, 2020].

Wyszyński S., Akt oddania się Matce Bożej, in: http://centrumzawierzenia.jasnagora.pl/akt-oddania-matce-bozej-ii/ [derived: June, 14, 2020].

\section{Printed sources}

Wyszyński S., A była tam Matka..., Warszawa 2001.

Wyszyński S., Akt oddania Polski w macierzyńska niewole Maryi, Matki Kościoła, za wolność Kościoła Chrystusowego, Jasna Góra, 3 maja 1966, in: Matka Odkupiciela Matka Kościoła. Dokumenty, eds. A. Wieczorek, Warszawa 1990, 29-41.

Wyszyński S., Do Solidarności. Rady i wskazania, Warszawa 1996.

Wyszyński S., Dzieła zebrane, vol. 5, 1959, Warszawa 2006.

Wyszyński S., Głos z Jasnej Góry, Warszawa 1984.

Wyszyński S., Godność kobiety, Warszawa 1998.

Wyszyński S., Gody w Kanie, Paris 1962.

Wyszyński S., Każda prawdziwa miłość z Boga jest. Bachledówka 22.07.1968, in: Kazania i przemówienia autoryzowane 1956-1981, vol. 29, p. 152.

Wyszyński S., Kromka chleba, Warszawa 2008.

Wyszyński S., Kultura zaczyna się pod sercem matki ... Stowo na zakończenie Tygodnia kultury chrześcijańskiej. Warszawa - kościót św. Anny 30. 04. 1977, in: Kazania i przemówienia autoryzowane 1956-1981, vol. 57, Warszawa 1981, p. 212-218.

Wyszyński S., Matka Kościoła, Watykan 1966.

Wyszyński S., Matka Syna Człowieczego, Poznań 1984. 
Wyszyński S., Miłość miłosierna, Warszawa 1998.

Wyszyński S., Miłość na co dzień. Rozważania, Warszawa-Ząbki 2001.

Wyszyński S., Na drogach zawierzenia, Warszawa 1996.

Wyszyński S., Nie gaście ducha ojca Maksymiliana, Niepokalanów 1996.

Wyszyński S., Nie oczekujemy życia łatwego. Podczas ingresu do katedry lubelskiej 26.05.1946, „Wiadomości Diecezjalne Lubelskie” 23 (1946), p. 161-174.

Wyszyński S., Owoce pokornego postugiwania i ufności ku Pani Jasnogórskiej. W 16. rocznice konsekracji biskupiej, Jasna Góra, 12.05.1962, in: S. Wyszyński, Dzieła zebrane, Styczeń - Lipiec 1962, vol. 8, Warszawa 2009, p. 318-329.

Wyszyński S., Pracujemy wszyscy nad wprowadzeniem w życie Ślubów Jasnogórskich, in: Wszystko postawitem na Maryje, Paris 1980.

Wyszyński S., Rozważania o Matce Boga-Człowieka, Jasna Góra 1983.

Wyszyński S., U stóp Patronki polskiej młodzieży akademickiej, Jasna Góra (10.05.1959), in: S. Wyszyński, Uświęcenie pracy zawodowej, Paris 1963, p. $143-148$

Wyszyński S., Wszystko postawitem na Maryję, Paris 1980.

\section{Elaborations}

Czaczkowska E.K., Kardynat Wyszyński: Bibliografia, Kraków 2013.

Dziuba A.F., Polityczny wymiar aktywności chrześcijańskiej w nauczaniu Księdza Prymasa Stefana Wyszyńskiego, in: Nauczanie społeczne Kardynała Stefana Wyszyńskiego, eds. A. Garbarz, Rzeszów 2001, 45-94.

Ficek R., Christians in Socio-Political Life. An Applied Analysis of the Theological Anthropology of Cardinal Stefan Wyszyński, Primate of Poland, Torun 2020.

Krukowski J, Stanowisko Prymasa Stefana Wyszyńskiego w sprawie normalizacji sytuacji prawnej Kościoła w Polsce, „Roczniki Nauk Społecznych” 10 (1982), p. 59-75.

Lewandowski J., Wychowawcze aspekty Wielkiej Nowenny w nauczaniu Kardynata Stefana Wyszyńskiego, „Chrześcijanin w Świecie” 116 (1983), no 5, p. 9-30.

Madajczyk P., Orędzie biskupów z 1965 r. jako element obchodów mileninych, „Więź” 145 (1997), p. 144-151.

Micewski A., Kardynat Wyszyński: Prymas i mąż stanu, Paryż 1982.

Nitkiewicz B., Jasnogórskie śluby narodu: milenijne zobowiazanie na dzisiaj, Wroclaw 2016.

Pylak B., Stefan Wyszyński biskup lubelski, Lublin 1999, p. 28-37.

Wyszomirski R., Maryjna droga kardynała Stefana Wyszyńskiego, “Tarnowskie Studia Teologiczne" 34 (2015), no 1, p. 47-65. 
Zawadka J., Wielka Nowenna w koncepcji duszpasterskiej Prymasa Wyszyńskiego: zarys problematyki pastoralno-historycznej, „Warszawskie Studia Teologiczne” 24 (2011), no 1, p. 243-254.

\section{Mariologiczny wymiar teologiczno-pastoralnych koncepcji Kardynała Stefana Wyszyńskiego, Prymasa Polski}

\section{Streszczenie}

W powyższym artykule zaprezentowano analizę jednego z fundamentalnych aspektów nauczania Kardynała Stefana Wyszyńskiego jakim jest mariologia rozumiana w kategoriach prakseologicznych. Podjęta przez autora eksplikacja materiałów źródłowych ma za zadanie ukazać zaufanie do Maryi, Matki Kościoła, które odegrało niewątpliwie ogromną rolę w życiu i posłudze biskupiej Kardynała Wyszyńskiego. Rola i przymioty Maryi wpisane zostały tutaj w praktykę duszpasterską mającą na celu integralną odnowę moralną człowieka i narodu polskiego. Co więcej, opracowany przez Prymasa maryjny program duszpasterski oparł się naciskom komunistycznego aparatu władzy państwowej. Dzięki temu, stał się odpowiedzią na wiele zagrożeń, jakie niosła ze sobą powojenna rzeczywistość społeczno-polityczna, przyczyniając się do zachowania tożsamości i niezależności kulturowej Polaków.

Zamierzeniem autora powyższej publikacji jest syntetyczne ukazanie spojrzenia Kardynała Stefana Wyszyńskiego na Maryję jako na Matkę Boga-Człowieka i Matkę Kościoła. Eksploracja powyższych badań opierać się będzie na analizie tekstów źródłowych dokonywaną metodą historyczno-teologiczną. W konsekwencji, autor niniejszego artykułu starał się uchwycić i zarysować nie tylko mariologię Prymasa Tysiąclecia i zawarte w niej istotne treści teologiczne. Ważnym elementem powyższych badań jest ukazanie jej wymiaru pastoralno-prakseologicznego, przejawiającego się w różnorodnych inicjatywach duszpasterskich, w których nie tylko wyidealizowany pietyzm i admiracja, ale przede wszystkim głęboka wiara i zaufanie do Maryi Królowej Polski i Matki Kościoła odgrywały fundamentalną rolę.

Słowa klucze: Kardynał Stefan Wyszyński, mariologia, Matka Boża, personalizm, program duszpasterski, odnowa moralna, Śluby Narodu

\section{Summary}

This article presents an analysis of one of the fundamental aspects of Cardinal Stefan Wyszyński's teaching, which is Mariology understood in praxeological terms. As the source materials' research confirms, veneration and trust in the Blessed Virgin Mary undoubtedly enacted a significant role in the life and episcopal ministry of Cardinal Stefan Wyszyński. Moreover, the Marian pastoral program developed by the Primate resisted the communist apparatus of state power pressure. As a result, it became a re- 
sponse to many threats posed by post-war social and political reality, contributing to preserving the Polish people's identity and cultural independence.

The author of this paper intends to present Cardinal Wyszyński's teaching on the Blessed Virgin Mary, apprehended as the Mother of God-Man and the Mother of the Church. The exploration of the above research will be based on analyzing source texts using the historical and theological method. Consequently, the author of the article will try to capture and outline not only the Mariology of the Primate Wyszyński and the crucial theological substance it contains. However, an essential element of the above research will expose its praxeological dimension manifested in various pastoral initiatives monitored by the then Church in Poland.

Thus, the reverence and veneration of the Blessed Virgin Mary, Queen of Poland, and Mother of the Church have played a fundamental role. The culminating moment on the Marian way of Cardinal Wyszyński's episcopal service was the act of total dedication to Mary in the spirit of St. Louis Maria Grignion de Montfort. The pastoral programs that emerged as a consequence of this Vows enacted a pivotal role in maintaining the faith and Christian tradition by the Nation, strengthening the postwar Church in Poland, as well as impacting the entire universal Church.

Key words: Cardinal Stefan Wyszyński, Mariology, Mother of God, personalism, pastoral program, moral renewal, Nation's Vows 
